\title{
Management of Ships and Shipping Companies the Digital Way: What Is Ahead?
}

\author{
Alexandros M. Goulielmos ${ }^{1,2}$ \\ ${ }^{1}$ Marine Economics, Department of Maritime Studies, Faculty of Maritime and Industrial Studies, University of Piraeus, Piraeus, \\ Greece \\ ${ }^{2}$ Shipping, Transport and Logistics Department, Business College of Athens, Athens, Greece \\ Email: ag@unipi.gr,am.goulielmos@hotmail.com, agoulielmos@bca.edu.gr
}

How to cite this paper: Goulielmos, A. M. (2020). Management of Ships and Shipping Companies the Digital Way: What Is Ahead? Modern Economy, 11, 1263-1279. https://doi.org/10.4236/me.2020.117090

Received: May 24, 2020

Accepted: July 12, 2020

Published: July 15, 2020

Copyright (C) 2020 by author(s) and Scientific Research Publishing Inc. This work is licensed under the Creative Commons Attribution International License (CC BY 4.0).

http://creativecommons.org/licenses/by/4.0/ (c) (i) Open Access

\begin{abstract}
As the world moves rapidly toward the fourth industrial revolution, and 5G, we analyzed the status of the international shipping industry, particular in Greece, which together with EU, lagged behind in relation to digital management. Throughout history, mankind has dreamed of automating mechanical processes, and succeeded in producing more goods with less power, based on the economic principle. But the quality of goods (and of human life) was left out of the analysis. We tried to correct this oversight in the Appendix. Not much has changed to this day as in the last 270 years, as robots, and other means, are used now to increase productivity. As we show, the tension now is between humans and machines. This antagonism is not about productivity, since there is no doubt that machines are more productive, but about who is more intelligent. Humans have natural intelligence, but machines have artificial one. Some argue that machines are inferior in many areas, such as medicine, agriculture, finance, management, education, distribution, transportation and maritime management.
\end{abstract}

\section{Keywords}

Ship Management, Global Technology, EU, Artificial Intelligence, Classification Societies, Shipyards

\section{Introduction}

Humans know that information, and knowledge, are vital and a substantial extra power in all human endeavors, and especially for business. Thus they introduced an "information technology" revolution (2000-2010) which resulted in an increased mechanization and automation.

Remote management of ships, as applied today, and for many decades, ob- 
liged shipping companies to create many written instructions to guide vessel's personnel in a management process known as "formalization". This was combined with continuous monitoring of vessels by the operating company, using mobile phones and e-mails in carrying-out its daily duties.

A traditional method of monitoring ships was to prepare written reports, after an on-board inspection by a qualified person from land-office. Remote management created certain costs, the level of which no one ever calculated. But it, while it may create some costs, will reduce others. Some argue that digitization will increase income, because there is an app on the market related to chartering (mentioned below).

Shipowners tried to reduce the impact of remote management by conducting "management by walking around" at land-based offices. In addition, the responsibility for managing ships remotely fell mainly on the shoulders of captains, as managers of ships, and secondarily on chief engineers, who are onboard. This situation unfortunately had a number of serious (economic) consequences.

The remote monitoring of ships, using means that were not totally effective and efficient, may have produced a false confidence among shipowners that they could manage their ships from a great distance. This may be seen as analogous to the problems on social media of fake news, where false stories circulate because it can be difficult to check authentic sources of information.

The ability for land-based managers, technical staff and insurance operators to see, in a video, or in real time using a number of cameras, an accident occurring on a ship which is hundred miles away, will be an extremely valuable service.

\section{Literature Review}

Digital management of shipping companies and ships is an entirely new subject, and there is little literature on the subject. Goulielmos (2020) devoted only a limited space to the topic.

Lambrou et al. (2019) addressed the digitization of shipping management. Of their 51 sources, only two dealt with shipping, one with ports and one with EU transport policy. As Professor Lambrou commented in a private mail, their joint paper was like a second doctoral thesis for her.

Columbia Marlow (cited in Nicholls, 2018) argued that shipping digitization is an existential issue. In a survey for Singapore Maritime Week (2018), the audience indicated that digitization is a real issue (82\%). Another recent shipping survey found that most maritime industry executives saw digitization and big data as forces of transformation. Only $9 \%$ of respondents saw digitization to be a major part of their operations.

Companies in Greece that wanted to be digitally transformed said that they could not find digitally educated staff. In recent research (IDC, 2019, April, for Microsoft) carried out in Greece, and in four other Eastern European countries including Russia, Greeks stated that there is a lack of persons who are digitally literate. 


\section{Aim and Organization of Paper}

Remote monitoring of shipping has not been as effective and efficient as it could be. The aim of the paper is to examine ways to transform management, by using digital means, to look into ships, so that the owners can have the advantages of being on-board, even though they are actually a long way away. The target is the real time observation of ships, using telecasting to reduce, artificially, the distance between the vessel and her land-office.

The paper is organized as follows. After literature review, Sections 1, deals with technological progress around the globe, in EU and in shipping industry. Section 2, looks for how to achieve a closer management of ships, and Section 3, examines the opportunities offered by artificial intelligence. Section 4 , addresses the question of maritime digital transformation and Section 5 the role of classification societies in ship digitization. Finally, the paper concludes.

\section{Section 1: The Status of Technological Progress in Globe, EU and in Shipping Industry}

\subsection{Global Technological Progress}

Technological developments take place all the time (Table 1).

Important changes have taken place, especially in personal communications. The technology of smart phones, cameras, sensors and tablets is constantly progressing and improving to make them smaller and, more important, tailor-made. The trend toward customizing is in the right direction, we believe. A manager should receive only the information he or she needs, avoiding overloading, as managers have limited time. Big data is also welcome, but only if tailor-made.

\subsection{Technological Progress in EU}

The three economic blocks: USA, EU, and China, compete and argue over digitization, and what is to follow (5G). Data will soon be a strategic product, and some countries will export them.

What can the EU can offer its business firms, including shipping firms, in advanced technology (Tables 2-5)?

Table 1. Global technological changes since 1980.

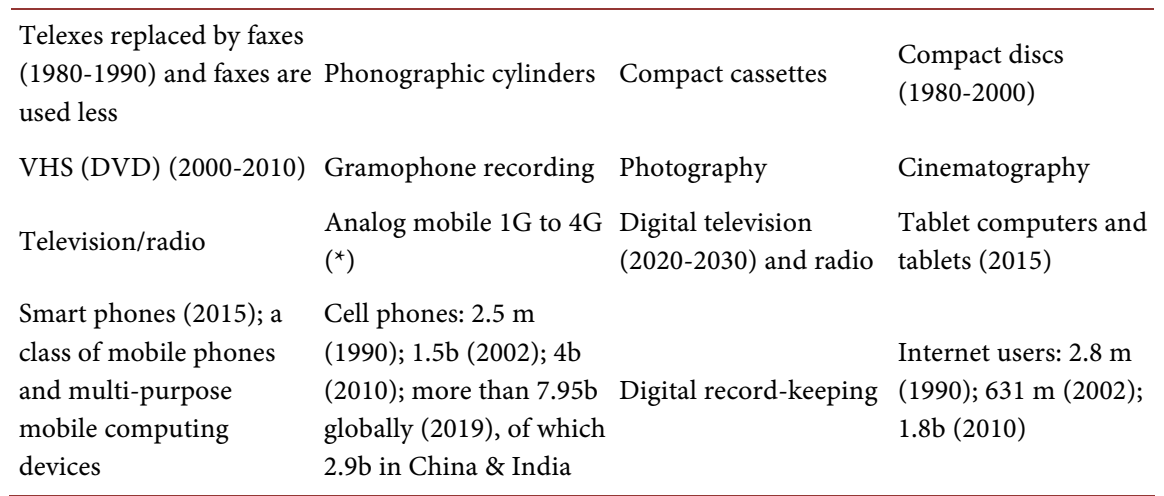

Source: author. $\left(^{*}\right) 5 \mathrm{G}$ is on the way, the next major phase in mobile telecommunications. 
Table 2. Europe is pioneer in.

\begin{tabular}{llll}
\hline $\begin{array}{l}\text { Chatbots (machines with } \\
\text { specific software talking to } \\
\text { humans in real time } \\
\begin{array}{l}\text { self-educated) } \\
\text { fellecting methane (ammable ice from }\end{array}\end{array}$ & $\begin{array}{l}\checkmark \text { Submerged human } \\
\text { communities }\end{array}$ & $\begin{array}{l}\text { Bioplastics (from } \\
\text { corn, rice, }\end{array}$ \\
$\begin{array}{l}\text { Chip laboratories (small of oceans } \\
\text { producing natural gas) } \\
\text { machines carrying-out tests } \\
\text { at high speed) }\end{array}$ & $\begin{array}{l}\checkmark \text { Quantum } \\
\text { cryptography }\end{array}$ & $\begin{array}{l}\text { potatoes, tapioca, } \\
\text { wheat fibers \& } \\
\text { wooden cellulose) }\end{array}$ \\
\hline
\end{tabular}

Source: EU's "White Book" (Feb. 2020).

Table 3. Europe is very strong in.

\begin{tabular}{|c|c|c|c|}
\hline $\begin{array}{l}\checkmark \text { Voice recognition } \\
\checkmark \text { Gene processing } \\
\checkmark \text { Out-of-body } \\
\quad \text { machines }\end{array}$ & $\begin{array}{l}\text { Neuro-type chips (mimic } \\
\text { human brain) (used in } \\
\text { recognizing objects, voice, } \\
\text { gestures, analyzing feelings, } \\
\text { health, robot movements, \& } \\
\text { measuring energy } \\
\text { consumption) }\end{array}$ & $\begin{array}{l}\checkmark \text { Flexible electronic } \\
\quad \text { devices } \\
\checkmark \text { Super-spectral } \\
\text { representations } \\
\quad \text { (tele-tracing) }\end{array}$ & $\begin{array}{l}\text { Swarm intelligence } \\
\text { (info. systems mimic } \\
\text { the swarm behavior of } \\
\text { insects or birds, used } \\
\text { in cars with no driver, } \\
\text { rescue-robots, drones, } \\
\text { combat systems (De- } \\
\text { huri et al., 2011) }\end{array}$ \\
\hline Blockchain & $\begin{array}{l}\text { Sensors of bio-breaking (used } \\
\text { as medical implants for fast } \\
\text { discovery of a body } \\
\text { malfunction, drug release \& } \\
\text { tissue rebuilding) }\end{array}$ & & \\
\hline
\end{tabular}

Source: EU's “White Book” (Feb. 2020).

Table 4. Europe has a mature trend in.

\begin{tabular}{lll}
\hline Nanotechnology (led; & $\checkmark$ New holograms & $\checkmark$ Gene processing \\
coal pipes; pipes) & $\checkmark$ Accurate agriculture & $\checkmark$ Bio-breaking sensors
\end{tabular}$\quad$ Autonomous ships

Source: EU's “White Book” (Feb. 2020).

Table 5. Europe has to try harder in the areas below.

\begin{tabular}{llll}
\hline $\begin{array}{l}\text { Computers with } \\
\text { stronger memory }\end{array}$ & 4-D printing & Bio-brightness & $\begin{array}{l}\text { Automatic internal } \\
\text { agriculture }\end{array}$ \\
$\begin{array}{l}\text { Splitting water in } \\
\text { oxygen \& hydrogen } \\
\text { (new technique) }\end{array}$ & $\begin{array}{l}\text { Liquid salt reactors (safe } \\
\text { \& nuclear) }\end{array}$ & $\begin{array}{l}\text { Transistors from grapheme } \\
\text { (making devices smaller \& } \\
\text { extremely faster) }\end{array}$ & $\begin{array}{l}\text { Gathering energy } \\
\text { from natural sources }\end{array}$ \\
Hyper-loops & Thermoelectric painting & Artificial brain joining & Flying cars
\end{tabular}

Source: EU's “White Book” (Feb. 2020).

As shown, chatbots, chip laboratories and 3-D food printing will be used in shipping and in business in general.

All the above technologies can be used in shipping, and not only those that seem to be specifically designed for. Blockchains are already used in shipping and in business in general.

Nanotechnology can replace ships' pipes. One revolutionary application is autonomous ships, which, if also electric, will kill two birds with one stone: zero 
emissions and zero crew.

Vessels might generate electric power using fuel other than diesel, and may include nuclear energy with zero emissions. Painting and coating ships using digital tools is already in use. But the EU fell behind in providing computers with faster memory, which is a serious disadvantage in projects such as 4-D printing.

More important are the applications that are related to cheaper, cleaner, safer and more abundant energy. All human endeavors were connected, since creation, with energy. Some talk today about "smart energy". As with the economy, EU thought it proper to establish a single data market, so that European firms would have better access to data produced within EU borders (Reuters, 2020).

\subsection{Electronic Technology in Shipping}

Persons with a rather long experience in a shipping company remember the electronic applications used since 1970s (Table 6). The transition from main frame computers (in dedicated, air conditioned cold rooms; batch technology) to personal computers was not always automatic in shipping companies.

Every shipping company has to move from analogue mechanical and electrical technology, to digital technology, if they have not done so already. This has been a change taking everywhere since 1980. All machines are expected to become digital by 2028 .

Norway, a major maritime nation, established the Norwegian Maritime Competence Center in Aalesund in 2012, where digitization, automation and robotics were key areas for development. This made up of 18 shipowners, 13 design firms, 14 shipyards, a university campus (Norwegian University of Science and Technology), a hub, many closed seas (fjords), \$14 m worth of sensors (for winds, waves and currents) and 8 ferry companies.

In that center, the data stream analyzed on vessels found that small adjustments to ship operations can have a great impact on fuel consumption, reduced by almost $20 \%$ on a test vessel. The United Arab Shipping Company estimated that it saved $3 \%-5 \%$ by having real time access to fuel prices, ship locations and routes.

Table 6. Maritime electronic applications, 1960-2020.

\begin{tabular}{llll}
\hline Mainframes & $\begin{array}{l}\text { Use of personal } \\
\text { computers (1980s) }\end{array}$ & $\begin{array}{l}\text { Cargo information } \\
\text { management }\end{array}$ & $\begin{array}{l}\text { Computer stowage } \\
\text { (per ship type) }\end{array}$ \\
$\begin{array}{l}\text { Ship operations } \\
\text { management systems }\end{array}$ & $\begin{array}{l}\text { Autopilot (automatic } \\
\text { steering) }\end{array}$ & $\begin{array}{l}\text { M zero: specification for an } \\
\text { unmanned night operation } \\
\text { engine room }\end{array}$ & $\begin{array}{l}\text { Integrated control } \\
\text { monitoring system }\end{array}$ \\
Bill of lading & $\begin{array}{l}\text { Electronic navigational } \\
\text { charts (1990s) }\end{array}$ & Track control system (1990s) & GPS (1990s) \\
& $\begin{array}{l}\text { Electronically controlled } \\
\text { Mobile terminals }\end{array}$ & Digitization (2020s) & \\
\hline
\end{tabular}

Source: author's experience; plus Ando (2019). 


\section{Section 2. A Closer Management of Ships}

\subsection{Terminology Used}

With digitization, it is better to be clear about what we mean (Graph 1).

The first, simple job for shipping companies is the conversion of their environment from a traditional analogue one to digital. Most shipping managers, however, sit back and wait. The maritime industry cannot be classified among aggressive industries in digitization like those shown (Graph 2).

Moreover, four areas where digitization can be useful are shown (Graph 3).

As shown, digitization can contribute not only to more efficient and effective management of ships, but also in the protection of the maritime environment and ships' safety. These two last areas are extremely important.

\subsection{A Digital Maritime Control Center and Department}

Shipping companies need to employ a chief digital officer. He/she will be in charge of the company's digital transformation, and he/she will have to transform IT department into a digital technology one. If there is already one IT manager, he/she will have to receive a digital education or appoint a chief digital officer as deputy manager.

The next, more difficult, step is to establish an operations room. Shipping companies should organize it so that data (and sound/and or picture if possible) from ships come-in 24/7. This center will become company's global operations

\begin{tabular}{|c|c|c|}
\hline Digitization & Digitization & $\begin{array}{l}\text { Digital } \\
\text { Transformation-DX, }\end{array}$ \\
\hline $\begin{array}{l}\text { If firm's data } \\
\text { are converted } \\
\text { to digital }\end{array}$ & $\begin{array}{l}\text { If firm's processes are } \\
\text { converted to digital }\end{array}$ & $\begin{array}{l}\text { If management, \& } \\
\text { firm's business model, } \\
\text { are reformed by digital } \\
\text { technology }\end{array}$ \\
\hline
\end{tabular}

Graph 1. The meaning of terms used in digitalization. Source: author.

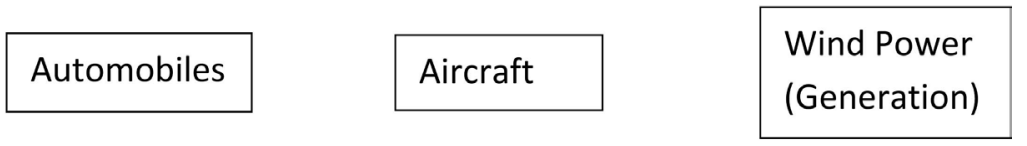

Graph 2. The aggressive industries in digitization. Source: author.

\begin{tabular}{|l|l|l|}
\hline $\begin{array}{l}\text { In using: } \\
\text { advances in } \\
\text { information } \\
\text { technology }\end{array}$ & $\begin{array}{l}\text { In increasing: } \\
\text { Environmental } \\
\text { Protection }\end{array}$ & $\begin{array}{l}\text { In making: more } \\
\text { effective } \\
\text { utilization of data } \\
\text { generated in/by } \\
\text { ships }\end{array}$ \\
\cline { 2 - 2 }
\end{tabular}

Increase:

Safety and

Efficiency

Graph 3. Areas where maritime industry can be ahead of other industries in digitization. Source: author. 
and control center, where a number of computer screens relay videos, data, and keep watch on company's ships and their operations in ports and at sea worldwide.

Thus company's operators will have online information on loading/unloading, maintenance, and the navigation of ships. Cameras and sensors need to be installed in all places of particular interest onboard, and can also be used by captain and chief engineer.

\subsection{Managers as Digital Engineers}

Nowadays, we have a number of methods of surveillance at a distance. These can be used to manage by looking into vessel's operations. These applications provide immediate, online, feedback, delivered by mobile devices or video (Goulielmos, 2019). Shipping managers nowadays must be digital engineers, by using digital tools (Graph 4).

In general management theory, a manager deals with digitization as part of planning. For a shipping manager, we suggest this to be his/her additional, $5^{\text {th }}$ function. As shown (Graph 4), there are two kinds of intelligence: 1) about a company's competitors and 2) about a company's business (Tarras \& Molz, 2006). The latter is different from external analysis in the SWOT model and it is called environmental scanning.

For the shipping industry, environmental scanning is even more important than for land-based industries, because shipping is an international industry influenced by all major global events. The company should screen information to detect all emerging events that may affect company.

More important, however, is "competitor intelligence", or basic information about competing companies. Research indicates that competitor intelligence is available and accessible to the public, and it only needs digital tools (Zimmermann, 2002). Secretive shipping companies have revealed some of their secrets by creating websites and listed in stock exchanges.

Next section presents the case of a listed shipping company, as an example of competitor intelligence.

\subsection{A Case-Study of a Tanker Company Listed on the NYSE (1992) (Stelmar Shipping Co Ltd.)}

The company owned 31 ships, $1.76 \mathrm{~m} \mathrm{dwt}$, in 2002. Its emphasis was on handy$\max (46 \%)$. The company's shipbuilding policy was to focus next on Panamax (347,044 dwt; $62 \%$ of the total fleet). The company ignored economies of scale.

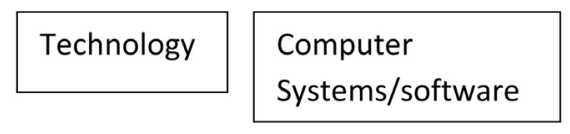

Business intelligence \&

Competitor Intelligence

\section{Collecting, visualizing, understanding $\&$ analyzing data}

Graph 4. Managers: “Digital Engineers” \& their tools. Source: author. 
Ships had a uniform speed (around 15 knots) and were flagged in Cyprus (22 new-buildings) and Panama (14 units).

The company's chartering policy (since 1997) is important. Company "stuck" to time-charters gaining a return $9.4 \%$ on average on capital employed. The reasons given for this policy were to achieve: 1) a steady cash-flow, 2) higher fleet utilization and 3) secure current and future income. The company stated that it also focused on cost-effective operations, to be below the industry average on cost.

The company missed profitable periods in the spot market by sticking to time charters, but argued that its chartering brokers determined the duration of time charters so that it could profit from rises in rates. These arguments may not be very convincing. The company provided its organizational chart as in Graph 5.

Company's six departments employed only 28 persons. This is a rather economic size. But two departments seem to be over-staffed: finance and technical. Indeed for tanker owners, emphasis on technical aspects of the ships is to be expected. A listed company may also have a large finance department. Persons in managerial posts above staff are not different from those in management of the departments.

A competitive advantage of this company is the low average age of its ships (7.2 years in 2002). Another competitive advantage is the limited off-hire days of ships $(82 / 175 ; 100 / 215 ; 88 / 219 ; 308 / 321 ; 342 / 513$ in $1998-2002)$. The denominator is the theoretical maximum. This is a result of the time-charter policy of the company, where no time is lost between charters.

\section{Artificial Intelligence}

A vessel is a giant machine, or rather a set of machines and devices/appliances, where artificial intelligence (AI) finds extremely fertile ground. AI dates back to 1956 (McCarthy et al., 1956), and is a set of ideas, technologies and techniques, related to the ability of a system, or of a computer, to execute orders, which in normal circumstances would require human intelligence. AI is connected with

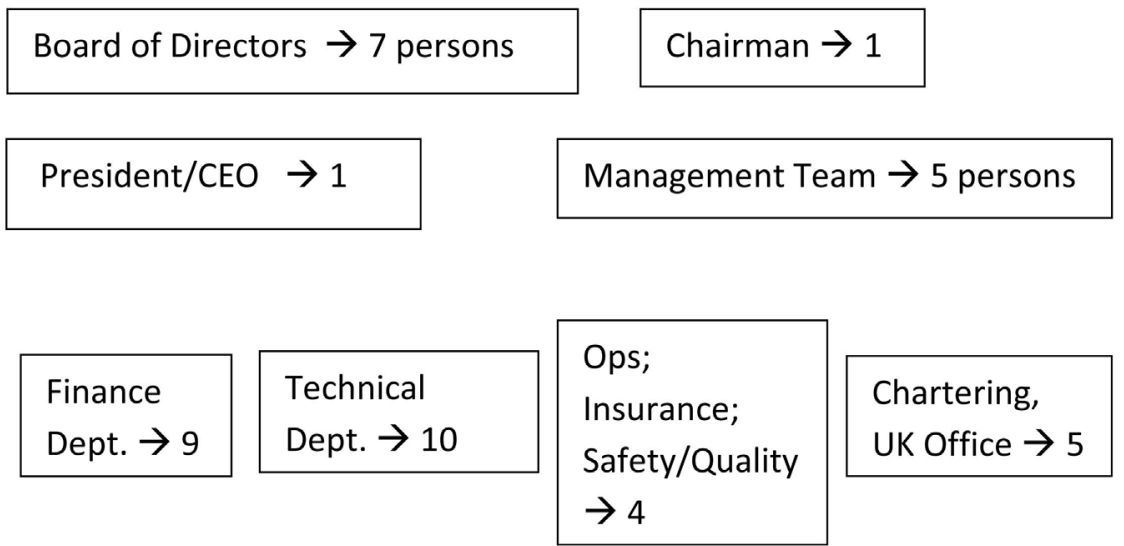

Graph 5. The organizational chart of "Stelmar Shipping Co Ltd.”, 2002. Source: author, on data from company's report. 
particular software, or with a particular system, which imitates the mental work of human brain.

There are programs, which comprehend human language, perform logical reasoning and learn from experience, like expert systems. Expert systems imitate the problem-solving methods used by specialists. They automatically translate, interpret images and sounds, and recognize speech. AI transcribes texts from a magnetic recorder or reads mechanical filters of a ship's waste water.

It is important to be able to re-cast data and organize them the way the manager wants; or for a crew member to retrieve on a computer screen all the relevant information on a theme (laws, conventions, regulations, circulars, manuals etc.). AI makes formalization more practical and useful.

Machines have the (automatic) ability to learn from, and adapt to, new data (with no human intervention) (EU Observer, 2019). The help of intelligent machines emerged during the current fourth industrial revolution. Humans succeeded in devising methods to rectify certain of their weak points, as was also clearly indicated by the first three industrial revolutions. The fourth industrial revolution is based on two recent reinforcing/cooperating innovations: computerization and digitization.

Humans are intelligent creatures, and have used technology for the "common good", but they have certain disadvantages: they cannot process big data, have a lower processing speed, respect hierarchy which acts as brake on decision-making, and use sentimental thinking. Thus, humans called upon technology to make-up for their disadvantages. AI was promoted in the hope that one day mechanical intelligence will be superior to human intelligence ...

AI adds to human mental artillery. The dominant global players (USA; China; EU) understood the importance of this, but the EU is already behind. This is an important area. The problem today is not collecting information, as this was accomplished by computers a few decades ago, but to store, retrieve and handle big data for manager's benefit.

The EU rightly suggested a legal framework, so that AI would obey certain rules. Many people nowadays receive messages on their mobile phones from the state to be aware of a danger, or to act accordingly, a facility that was unknown before.

Data come-in (in big) waves and these will become the raw material for any future 5th industrial revolution ("Le Monde, 2019"). This will concern not only the business world, but the internet of things. People will be able to receive automatic messages on their smart phone, email, tablet or computer, only the information they are interested in $24 / 7$.

Table 7 summarizes the history of AI.

It may be a surprise, but machines ... may take over management from humans by being more intelligent. This might be called "mechanical management" or "management by AI", and shipping managers should be prepared for it. But care must be taken that (intelligent) machines should not be managers' masters, but their servants ... 
Table 7. The evolution of AI, 1965-2020.

\begin{tabular}{|c|c|c|}
\hline$\underline{1956-1970:}$ & 1971-1996: & $\underline{1997-2009}$ \\
\hline $\begin{array}{l}\text { Appearance of term (1956); AI used to solve } \\
\text { complex mazes and puzzles (non-business } \\
\text { cases) (1965); expert systems emerged (1965) }\end{array}$ & $\begin{array}{l}\text { AI is in exploratory stage; academic interest } \\
\text { attracted; computers were expensive; expert } \\
\text { systems (using fuzzy logic due to Zadeh, L.) } \\
\text { emerged stronger; Windows and Mac appeared; } \\
\text { computer prices fell; society became } \\
\text { computer-literate }\end{array}$ & $\begin{array}{l}\text { AI proved superior than best humans in certain } \\
\text { games (Othello and Chess); rule-based } \\
\text { processing systems emerged (1980-2000) }\end{array}$ \\
\hline $\begin{array}{l}\text { Machines learned and deeply; the } \\
\text { convolutional neural networks (CNN) } \\
\text { emerged: audio classification appeared (1988) }\end{array}$ & $\begin{array}{l}\text { Machines used for predictions in visual } \\
\text { recognition \& image recognition in advertising; }\end{array}$ & $\begin{array}{l}\text { Recognition of defective products and spare } \\
\text { parts; AI can be used to collect data on }\end{array}$ \\
\hline $\begin{array}{l}\text { and image (1989); AI closely related now to } \\
\text { business; AI can be used in seamen selection }\end{array}$ & $\begin{array}{l}\text { speed, wave's height; Captain can thus correlate } \\
\text { data to the age of ship etc. and he/she may }\end{array}$ & $\begin{array}{l}\text { AI can analyze information on ship and her } \\
\text { equipment, where fuel economies can reach }\end{array}$ \\
\hline providing a match between ship job \& & prefer a refugee port than ship's original route; & $\$ 20 \mathrm{~m}$ per annum for a fleet of 35 ships; technical \\
\hline big data; and by increased computer memory & character recognition) & performance and on her condition can be \\
\hline (1993); and by the use of GPUs! & & $\begin{array}{l}\text { monitored } 24 / 7 \text { and detect abnormalities (Gou- } \\
\text { lielmos \& Gatzoli, 2012) }\end{array}$ \\
\hline
\end{tabular}

Source: author; aided by Ando (2019).

Machines, run by humans, served humanity over the past 270 years, through four industrial revolutions. Machines have superb properties: they work 24/7; they are accurate; they adapt to digitization; they welcome maintenance/repairs and supervision; and they co-operate with computers. Originally machines had a disadvantage: they could not think, or learn, as humans could. But machines now learn, and improve their intelligence, mimicking humans.

\section{Forces Pushing towards Maritime Digital Transformation}

There are a number of developments/institutions, which will contribute to the digital transformation of shipping companies (Graph 6).

For a company to become digital, it must first obtain the data it needs, and buy suitable software, and then understand that the whole matter is a process, which needs not only tools, but also actions, money and time. Cloud computing (2015) is a very ingenious service, where computers' hard drives and/or a company's networks need not store data. But this is not the only benefit. The cloud is a place where one can find the data and information one wants about the company he/she manages.

One development (Graph 6) indicates indirectly the exceptional new products provided by industries, which manufacture sensors cheaper, better and able to give readings more frequently. Another is the long revolution in communications, where specialized companies sell bandwidths and private companies try to make connectivity faster and cheaper.

Shipping companies should create vessel support centers, installing fleet-wide satellite broadbands. Technology companies (manufacturers of all kinds of machines, appliances, and devices) are now interested not only in selling their products, but also in providing services (to shipping), supplementing their products, such as engines, navigational equipment and machinery. 


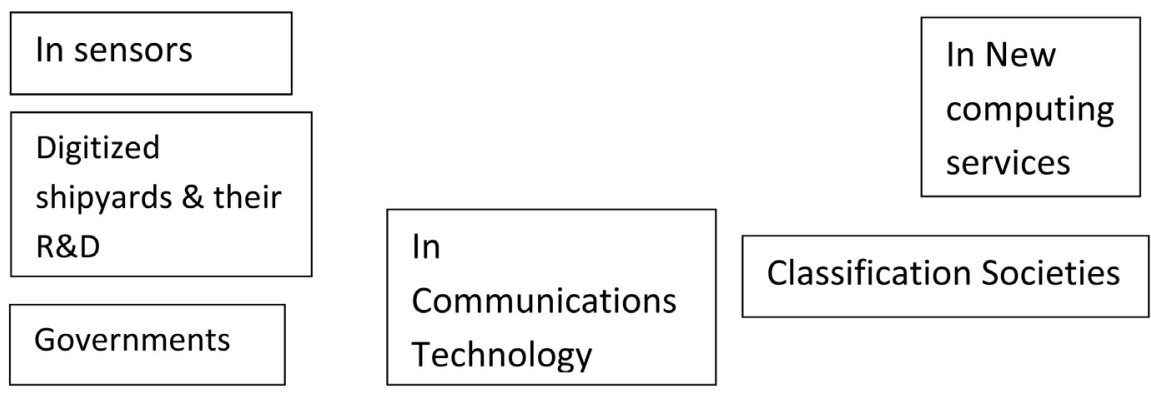

Graph 6. Important developments/institutions that will push shipping industry to become digital. Source: author.

\subsection{The Role of Governments}

An important push for land industries to digitize came from certain governments. In Germany this initiative named "Industrie4.0", meaning that industrial internet consortia/groups would improve the productivity of the internet of things. Germany adopted a high-tech strategic action plan-2020, which promoted R \& D in shipbuilding (2011). Also there is there a push towards smart factories, using cyber physical systems.

Japan's Ministry of Economy, Trade and Industry, adopted a strategy, called Society 5.0, connecting industries, and using ICT data applications, and a diverse workforce. (2018). The Japanese Ministry of Land, Infrastructure, Transport and Tourism subsidized R \& D costs to promote i-shipping and design, construction and operations of vessels

\subsection{Robots as Painters}

Small robots can be used to optimize the painting of ships, and applying coatings, using sensors to measure pressure, vibration, and temperature, and keep the spray-holes clean.

\subsection{The Internet of Ships}

Shipping is an excellent case of decentralized production, which digitization supports. Shipping managers should be among the first to the internet of things, or rather the internet of ships (https://www.forbes.com/ 16/12/2016).

\subsection{A Chartering Revolution}

Chartering was not influenced at all by the digital revolution before 2017. One shipping company (established in 2014) conceived an idea from the automatic identification system to achieve a $\$ 1000$ increase in a ship's profits using technology. It found that AI could help in understanding data related to charterers and aid ship-brokers to improve their bargaining ability. AI provides information about the number and names of competitors, and managers can act accordingly.

To achieve this, one has to create, or buy, a platform (software plus algorithm), which will analyze, and process, the plethora of data coming-in from 
cargo brokers by email. The platform by providing to company's operating ships (Aframax) relevant data, was capable of providing an additional income of $\$ 3,500$ per day above the global average in 2018 of $\$ 14,500$.

\subsection{Restrictive Factors in Ship Digitization}

There are a number of restrictive factors, however, in the adoption of digitization by shipping firms (Graph 7).

Universities have not prepared chief digital officers for shipping and a proper staff to supplement existing IT departments. Greek shipping companies have not been quick to adopt new technology, and for a long-time, they used to be the world's secondhand ship owners. There is a variety of reasons for this, but that goes beyond the scope of this paper.

Greek shipowners preferred to let others pull the chestnuts out of the fire. But now matters are different, because classification societies took the initiative to boost digitization in shipping companies. New products, including software, will make shipping companies transform themselves from analogue to digital.

\subsection{A Digital Strategy}

One strategy is to apply digitization to vessels in a gradual way starting from areas of greater importance (Graph 8). When shipping companies see that digitization brings benefits, they will attempt the required transformation.

If we can predict the weather, say one week in advance, we can have route-recommendations that could save $1 / 3$ of fuel cost, with no delay in arrival. What is generally recommended is to apply digitization in optimizing the performance of vessels (from trim to propeller). One can build predictive models based on analytics and data, from a vessel's past voyages. Vessels produce huge amounts of data, and where there are data, there is a digital opportunity ...

\begin{tabular}{|l||l|l|l|}
\hline $\begin{array}{l}\text { Small shipping } \\
\text { firms have } \\
\text { restricted } \\
\text { resources for } \\
\text { digital } \\
\text { transformation }\end{array}$ & $\begin{array}{l}\text { Difficult to find } \\
\text { and employ a } \\
\text { Computer Digital } \\
\text { Officer and a } \\
\text { proper digital } \\
\text { staff }\end{array}$ & $\begin{array}{l}\text { Shipping } \\
\text { firms } \\
\text { dislike } \\
\text { early } \\
\text { adoption }\end{array}$ & $\begin{array}{l}\text { Vessel's } \\
\text { remaining } \\
\text { life may } \\
\text { be short }\end{array}$ \\
\hline
\end{tabular}

Graph 7. Factors for delaying adoption of digitization by shipping companies. Source: author.

\begin{tabular}{|c|c|c|c|}
\hline $\begin{array}{l}\text { Adopting } \\
\text { weather- } \\
\text { optimal }\end{array}$ & $\begin{array}{l}\text { Building } \\
\text { predictive } \\
\text { models }\end{array}$ & $\begin{array}{l}\text { Dealing with } \\
\text { "human } \\
\text { element" }\end{array}$ & $\begin{array}{l}\text { Dealing } \\
\text { with an } \\
\text { easier }\end{array}$ \\
\hline
\end{tabular}

Graph 8. Application of digitization to ship areas where the biggest impact is. Source: author. 
There needs to be an online tracking and information system to provide information on ship security, navigation (location) and weather, giving information about where a ship is and what is doing. Digitization may modify captain's traditional role; he used to handle most information to and from the vessel. Digitization may, and should, reduce the reporting time of the moon reports. Changes in activity may be logged by pressing a button, while an automatic data collection of speed, fuel consumption, and so on, is already in use.

\section{The Role of Classification Societies in Ship Digitization}

Around 86,000 ships, worldwide, are designed and constructed on plans drawn by naval architects. These plans are approved (and supervised for their implementation) by classification societies, or classes for short. Classes are the official historians of ships, because they write ship's history from design, construction, and operation, on innovation, major repairs and accidents. And in response to the question of what to do with the data, everyone agrees that they should be used effectively from the ship's keel-laying to her scrapping (i.e. from birth to death).

One positive aspect of classes is that they compete with each other to attract ships to their lists. One service they offer is to prepare standards and guidelines for ship digitization. They also provide infrastructure, and platforms, and contribute to the digitization of the whole, or greater part, of shipping industry. Certain classes have already established a digital transformation center. Classes collect information digitally, but equally important is that they store, access and interpret data from (classified) vessels in a rather rapid way.

Another push to shipping digitization is from shipyards, which provide services, in co-operation with the shipping company and her class, during the construction of the vessel and at the stage of equipping her. In Figure 1, a ship and her digital twin are shown.

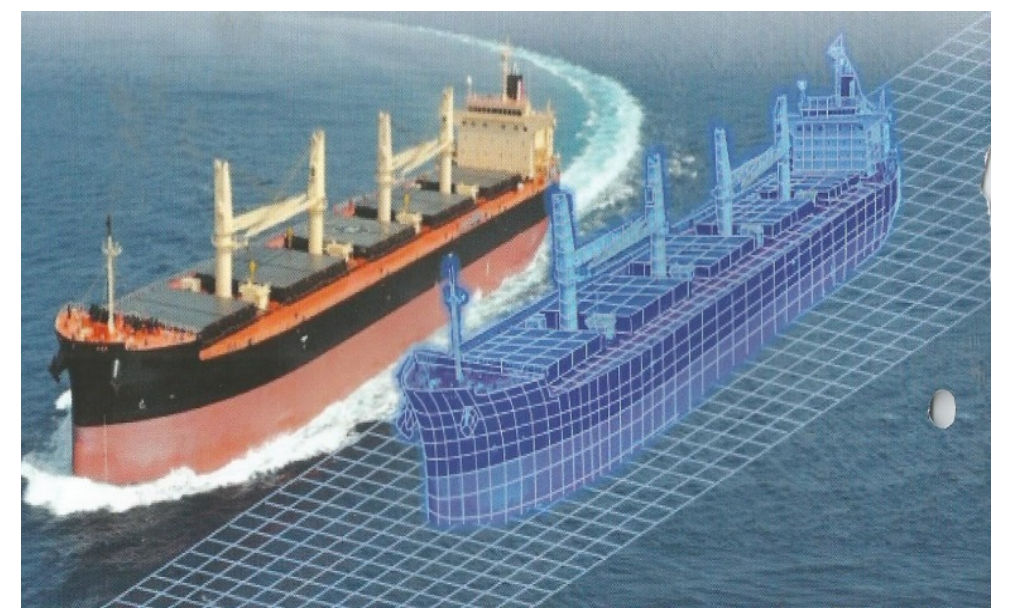

Figure 1. The ship and her digital twin. Source: ClassNK (modified) 2019; a digital twin is a reproduction of a ship simulating her movement and operational condition and can make predictions about her. 
A number of important issues are related to the activities of classes: 1) Hull maintenance: a specially designed information service is created to organize/categorize information collected from class surveys to provide owners/managers with full ship maintenance information; 2) Analysis of ship data: from onboard sensors (plus appropriate algorithms) to monitor the condition of a ship's machinery; 3) In-voyage optimization: planning, monitoring and following-up of ship operations to spot operational savings; 4) A secure data platform is provided for clients; 5) At least four important ship areas are monitored: hull, machinery, cyber security and sea condition (present/forecast).

\section{Conclusion}

The dream of shipowners to be at their office, thousand miles away from the ship they manage, and at the same time see into her entire life, in real time, is becoming true. A ship manager, artificially, has come back to his/her cabin onboard.

Greek shipowners used to be slow in adopting new technologies since they rested on the principle that foreign shipowners could take-up all the risks and sort out difficulties first. They were slow in adopting steam, in building new ships and gas carriers. Greeks disliked early adoptions. Progress in the country arrived first at the national branches of transnational enterprises, and then diffused to shipping.

But a number of strong forces are already pushing shipping firms towards digital transformation, including shipyards, classes, governments, manufacturers, the cloud and shipping research.

Digitization, as has been shown, is not only a means to reduce costs, but also a way to obtain higher profits/income. Moreover, safety is definitely increased, and piracy can be detected earlier and perhaps somehow prevented or avoided using drones onboard. (Drones are used already by classes.)

Many applications mentioned here can improve analysis to increase management's efficiency and effectiveness by providing information and knowledge to managers from ships on line. The ship, being a floating steel construction, a set of machines, appliances and devices, can use AI to become smarter. She may reduce black-outs and shut-downs, caring for herself. She can also ask for maintenance and repairs and talk to people in the land-office. She can choose the most economical navigational route and correlate her safety in relation to her condition to future weather. The available applications do not all centers on vessel, but also on crew, and passengers, as the case may be.

One by one the problems of ship digitization are being solved: broader broadbands, cheaper/safer clouds, a safer internet of ships, i-shipping, more effective and cheaper connectivity (more satellites), interoperability of all sources of data and information within a company and from all ships, to make for them better decisions and reduce operating costs. Data from all ships can give the whole picture of a company's entire production, and one ship can be compared 
with another to benchmark performance. Bandwidth is important for ships with a great number of crew and passengers. A typical cruiser in 2013 required 1 megabit/second and by 2018 needed 300 times that. Moreover, classes were proud to provide 9 main digital services, some mentioned above, to aid both shipping and shipbuilding, at a cost.

This paper has two limitations: 1) it deals with a subject in the making, and there are not many published sources, and established applications, and 2) it is based on the efficiency and effectiveness not so much of the shipping industry, which is in a deep slumber and dreaming of past glories, but of a number of strong players like classes, shipyards, manufactures, and governments. This "tsunami" will push the shipping industry up the hill of a new digital world, providing that humans remain in control of technology. Technology is a blessing and a curse at the same time.

\section{Conflicts of Interest}

The authors declare no conflicts of interest regarding the publication of this paper.

\section{References}

Ando, H. (2019). Digitalization in Maritime Industry. ClassNK Technical Journal, No. 1, 5-11.

Dehuri, S., Ghosh, S., \& Cho, S.-B. (2011). Integration of Swarm Intelligence \& Artificial Neural Network. Singapore: World Scientific. https://doi.org/10.1142/7375

Goulielmos, A. M. (2019). Plan the Business of a Vessel of a Tramp Shipping Company. Modern Economy, 10, 1633-1653. https://doi.org/10.4236/me.2019.106107

Goulielmos, A. M. (2020). From the Dynamics of Population to the Application of Digital Revolution to Management of Shipping Companies. Modern Economy, 720, 24-46.

Goulielmos, A. M., \& Gatzoli, A. (2012). The Role of a Ship's Master in Theory and Practice: Lessons from Marine Accidents. Journal of Critical Incidence Analysis, 55-78.

Lambrou, M., Watanabe, D., \& Lida, J. (2019). Shipping Digitalization Management: Conceptualization, Typology and Antecedents. Journal of Shipping \& Trade, 4, 1-17. https://doi.org/10.1186/s41072-019-0052-7

McCarthy, J., Minsky, M. L., Rochester, N., \& Shannon, C. E. (1956). A Proposal for the Dartmouth Summer Research Project on Artificial Intelligence.

Nicholls, S. (2018). Stratum Five. Ship Management International Journal, May/June 2018, 84-87.

Reuters (2020). Strategic Plan of EU in Handling Data. President of EC's Announcement, Feb. 2020.

Tarras, P., \& Molz, R. (2006). Competitive Intelligence at Small Enterprises. SAM Advanced Management Journal, 71, 24-34.

Zimmermann, K. A. (2002). The Democratization of Business Intelligence. KN World, 20-21. 


\section{Appendix: Quality of Food: A First Step towards Quality of Life?}

Industrial revolutions have increased production, even at higher prices. But this happened at the expense of quality of life, the most obvious example of which is climatic collapse. Increasing "friendship" of new (green) environmentally friendly technologies will be decisive for the future of mankind, and also for shipping industry. As Jesus said: "Man should not live by bread alone", indicating the need to think about the quality in life. But economists did not include the quality of goods in their theory of maximizing utility.

Assume that a consumer wants to maximize his utility function:

$$
U=f\left(q_{1}, q_{2}\right),
$$

by consuming $q_{1}$ and $q_{2}$ quantities of two goods, at a quality denoted by $Q_{1}$ and $Q_{2}$ and at prices $p_{1}$ and $p_{2}$. The combined quality/budget function is thus:

$$
Q^{0}=q_{1} p_{1} Q_{1}+q_{2} p_{2} Q_{2} .
$$

Rearranging (2) and solving for $q_{2}$, we get:

$$
q_{2}=Q^{0}-Q_{1} p_{1} q_{1} / Q_{2} p_{2} .
$$

Substituting in (1), we get:

$$
U=f\left(q_{1}, Q_{0}-Q_{1} q_{1} p_{1} / Q_{2} p_{2}\right) .
$$

Setting marginal utility, to zero and maximizing utility we derive:

$$
d U / d q_{1}=f_{1}+f_{2}\left(-Q_{1} p_{1} / Q_{2} p_{2}\right)=0 .
$$

Then

$$
f_{1} / f_{2}=Q_{1} p_{1} / Q_{2} p_{2} .
$$

Equation (6) means that the ratio of the utilities of the two goods must be equal to the ratio of their qualities/prices. If the consumer's budget is $\$ 100$, and quality ranges from 1 to 10 , quality and budget will determine the quantities bought (Figure A1), and the maximum utility obtained.

Example: Assume that the consumer chooses to buy 25 units of Good 1 at $\$ 2$, and pays a total of $\$ 50$, and 10 units of Good 2 at $\$ 5$, also for a total of $\$ 50$, in order to maximize his/her utility on an indifference curve, at point $\mathrm{E}$, all goods being assumed to be of quality rating at 10 . The line passing through $\mathrm{E}$ is given by:

$$
1000-20 q_{1}-50 q_{2}=0 .
$$

This line is important as it acts as a barrier to buying goods of low quality at the original prices. The utility function is:

$$
U=q_{1} * q_{2} .
$$

Combining this with $U=200-2 / 5 * q_{1}$ from (7) and solving for $\mathrm{q}_{2}$ and using marginal utility of $q_{1}$ as: $d U / d q_{1}=200-1 / 5 *(2)^{2} q_{1}$ (8) then $q_{1}=250$ and $q_{2}=$ 100.

If now quality falls to 8 , a reduction of $20 \%$, the consumer will buy 20 units of 


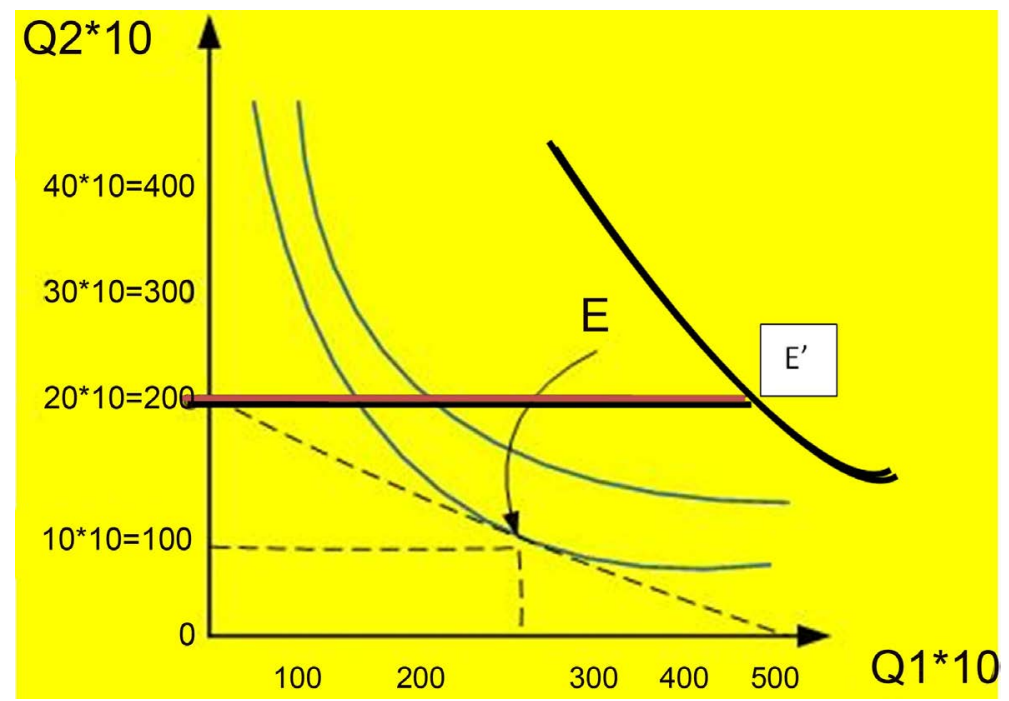

Figure A1. Maximizing utility at a fixed quality 10 ; or $8 / 10$.

Good 1 rather than 25 , and 8 Good 2 instead for 10 . Thus an inferior quality will cause a fall in quantities bought. The budget-quality line will move down and to the fall left. This means that utility will be less due to the lower quality at the original prices. This seems rational. If the consumer remembers the quality of goods bought previously, the amount spent will be lower and equal to $\$ 80$ instead of $\$ 100$. So, quality matters. If prices fall by $50 \%$, so that Good 1 costs $\$ 1$ and Good 2 costs $\$ 2.5$, then the quantities consumed will rise to 50 units and 20 units respectively (or 500 and 200 quality/quantity units), and the utility derived will be higher at E'. This also conforms to law of demand, i.e. when prices fall, quantities consumed rise (but only at top quality). 